\title{
EVALUASI PENYELENGGARAAN BADAN USAHA MILIK DESA (BUMDES) REJO MULYO, DESA GOGIK, KECAMATAN UNGARAN BARAT KABUPATEN SEMARANG
}

\author{
Adiatma Nugraha $^{1}$, Kismartini ${ }^{2}$
}

\begin{abstract}
All this time the development centered in the city, leading to gaps between villages and the city's economy. BUMDes become one of the ideas the government to boost the village economy. Gogik village which lies at the foot of mount Ungaran, Semarang Regency has the potential of natural recourses and clean water, its potential is not yet maximally utilized, Encouraged by Desa Lab Site PMD activities, Rejo Mulyo Village Enterprise was finally established in Gogik Village in 2011 with the hope of its ability to boost the village economic growth by the means of optimally utilizing its potential. Qualitative Descriptive method is used in this research by focusing on: (1) Evaluating the performance of BUMDes Rejo Mulyo, Gogik Village, District West Ungaran, Semarang Regency, (2) The supporting and obstacle factors BUMDes Rejo Mulyo, Gogik Village, District West Ungaran, Semarang Regency. The results of this research lead to a conclusion that the establishment of Rejo Mulyo Village Enterprise has already followed the valid regulation at that time, But the performance of BUMDes Rejo Mulyo is not maximized because it can not support the welfare of the villagers Gogik. One of the supporting factors of the performance BUMDes Rejo Mulyo is the spirit and willingness officials and employees to subserve the Gogik village. One of the obstacles faced, which is the biggest natural potential that exists in the Gogik village, are waterfalls Semirang it can not be utilized because the area is occupied in Perhutani area.
\end{abstract}

Keywords: Economic Disparity, Village Economy, Village Potential, and BUMDes

\section{PENDAHULUAN}

Ada anggapan bahwa Desa merupakan miniatur sebuah Negara karena di dalam Desa terdapat masyarakat, pemerintahan, wilayah, sumber daya, dsb. Namun realitanya Desa justru terabaikan di mana selama ini pengembangan ekonomi dan pembangunan dipusatkan di kota. Hal itu menimbulkan kesen-jangan antara Desa dan Kota. Desa tidak diberi keleluasaan mengolah potensi yang dimilikinya, yang terjadi justru potensi Desa dimanfaatkan untuk pembangunan ekonomi perkotaan.

Perubahan iklim politik dan pergantian pemerintahan diikuti dengan pergeseran paradigma pemba-ngunan dari Sentralisasi menjadi Desentralisasi. Hal itu bertujuan supaya daerah dapat memanfaatkan dan mengembangkan potensi yang dimilikinya dan

\footnotetext{
${ }^{1}$ Badan Pemberdayaan Masyarakat dan Desa, Kependudukan dan Catatan Sipil Provinsi Jawa Tengah

${ }^{2}$ Magister Administrasi Publik, Fakultas IImu Sosial dan Ilmu Politik, Universitas Diponegoro
} 
dimanfaatkan untuk pembangunan daerahnya. Hal tersebut memberikan "angin segar" bagi desa untuk dapat memanfaatkan, mengelola dan mengembangkan potensi yang dimilikinya. Salah satu gagasan pemerintah untuk membangun perekonomian desa, yaitu melalui pendirian BUMDes (Badan Usaha Milik Desa).

Gagasan tentang pembentukan BUMDes sebenarnya sudah tersurat dalam UndangUndang Republik Indonesia Nomor 32 Tahun 2004 tentang Pemerintahan Daerah. Namun baru pada tahun 2010 mekanisme pembentukan dan operasionalisasi BUMDes dijelaskan oleh Pemerintah Pusat melalui Peraturan Menteri Dalam Negeri (Permendagri) Nomor 39 Tahun 2010 tentang Badan Usaha Milik Desa. Pada tahun 2015 kemudian diperbaharui dengan Permendesa PDTT Nomor 4 Tahun 2015 tentang Pendirian, Pengurusan Dan Pengelolaan, dan Pembubaran Badan Usaha Milik Desa.

BUMDes diharapkan mampu menggerakkan roda perekonomian di perdesaan, di mana kelembagaan ekonomi tersebut dikelola sepenuhnya oleh desa dan masyarakatnya demi kemakmuran desa. Lembaga ekonomi ini tidak lagi didirikan atas dasar instruksi Pemerintah, tetapi harus didasarkan pada keinginan dan kesepakatan masyarakat desa berdasarkan potensi yang ada dan jika dikelola dengan tepat akan menimbulkan kegiatan ekonomi yang positif. Agar lembaga ekonomi ini tidak dikuasai oleh kelompok tertentu maka kepemilikan lembaga itu atas nama desa dan dikontrol bersama di mana tujuan utamanya untuk meningkatkan standar hidup ekonomi masyarakat (PKDSP, 2007:1).

Permasalahan yang sering muncul dalam pendirian BUMDes adalah seringkali Pemerintah Pusat hingga Pemerintah Daerah mendorong pendirian BUMDes hanya untuk memenuhi target program kegiatan dengan digelontor bantuan dana. Seringkali mereka juga tidak mendampingi BUMDes di wilayahnya, sementara itu Pemerintahan Desa juga seringkali dalam mendirikan BUMDes kurang memperhatikan potensi, Sumber Daya Manusia, dan sarana prasarana yang ada di desa. Alhasil BUMDes yang berdiri tidak berjalan maksimal sehingga pemasukan BUMDes tidak sesuai harapan bahkan mungkin malah merugi. Kalaupun sudah sesuai dengan potensi yang ada di Desanya, seringkali yang menjadi penghalang berdirinya BUMDes adalah pemasaran yang tidak maksimal dari para pengelolanya.

Pemerintah Pusat mendorong pembentukan dan perkembangan BUMDes di daerah, melalui pelaksanaan program kegiatan Desa Lab Site PMD oleh Balai PMD yang tersebar di beberapa wilayah di Indonesia sejak tahun 2011. Desa Gogik menjadi salah satu lokasi 
Desa Lab Site PMD dari Balai PMD Yogyakarta. Desa itu ditunjuk oleh Balai PMD dengan melihat potensi yang ada dan mendapat dukungan dari Pemerintah Daerahnya melalui penerbitan Perda tentang BUMDes. Kabupaten Semarang telah menerbitkan Peraturan Daerah Kabupaten Semarang Nomor 2 Tahun 2008 tentang Pedoman Pembentukan dan Pengelolaan Badan Usaha Milik Desa.

BUMDes Rejo Mulyo didirikan pada tahun 2011 berdasarkan Keputusan Kepala Desa Gogik Nomor 412.6/12/2011 yang kemudian dikuatkan oleh Perdes nomor 4 tahun 2011 tentang BUMDes. Dalam operasionalisasinya BUMDes Rejo Mulyo menyelenggarakan 3 (tiga) bidang usaha, yaitu : (1) Bidang Usaha Simpan Pinjam : Lembaga Keuangan Desa (LKD) Samirana; (2) Bidang Pengelolaan Air Bersih : Pengelolaan Air Bersih (PAB); (3) Pariwisata : Kelompok Sadar Wisata (Pokdarwis).

Tujuan berdirinya BUMDes Rejo Mulyo adalah untuk meningkatkan perekonomian Desa dan meningkatkan kesejahteraan masyarakat. Pendirian BUMDes ini juga dibidani oleh Balai PMD Yogyakarta melalui program Desa Lab Site-nya di tahun 2011. Pondasi dari BUMDes ini adalah Lembaga Keuangan Desa (LKD) Samirana yang bergerak dalam bidang ekonomi simpan pinjam sejak tahun 2002 sebagai inisiatif dari Pemda Kabupaten Semarang untuk memasyarakatkan LKD di seluruh Desa di wilayahnya. Selanjutnya setelah berdirinya BUMDes Rejo Mulyo, LKD Samirana dilebur menjadi salah satu unit usahanya.

\section{Tinjauan Pustaka}

\section{Kebijakan Publik}

Pengertian kebijakan publik menurut Thomas R. Dye "Whatever governments choose to do or not to do.", yaitu segala sesuatu yang dipilih oleh pemerintah untuk dilakukan atau tidak dilakukan. Bahwa apabila pemerintah memilih untuk melakukan suatu tindakan maka harus memiliki tujuan, kebijakan publik tersebut harus meliputi semua tindakan pemerintah, bukan merupakan keinginan saja. Disamping itu sesuatu yang tidak dilaksanakan oleh pemerintah pun termasuk kebijakan publik, hal ini disebabkan karena sesuatu yang tidak dilakukan oleh pemerintah mempunyai pengaruh yang sama besar dengan sesuatu yang dilakukan pemerintah (Wahab, 1989).

Tahap-tahap kebijakan publik menurut William Dunn, yaitu: 
1) Penyusunan agenda: mengenai kondisi-kondisi yang menimbulkan masalah, sangat penting untuk menentukan suatu isu publik yang akan diangkat dalam suatu agenda pemerintah.

2) Formulasi kebijakan: mengenai konsekuensi di masa mendatang dari ditetapkannya alternatif kebijakan, termasuk apabila tidak membuat kebijakan.

3) Adopsi kebijakan: mengenai manfaat bersih dari setiap alternatif kebijakan, dan merekomendasikan alternatif kebijakan yang memberikan manfaat.

4) Implementasi kebijakan: yaitu proses untuk melaksanakan kebijakan supaya mencapai hasil, pada tahap ini berbagai kepentingan akan saling bersaing.

5) Evaluasi kebijakan: melihat sejauh mana kebijakan yang dibuat telah mampu memecahkan masalah yang dihadapi masyarakat (dalam Subarsono, 2008).

\section{Evaluasi Kebijakan}

Evaluasi kebijakan dapat diartikan sebagai pengukuran efektivitas, efisiensi dan hasil dari implementasi kebijakan yang telah dilakukan berdasarkan dengan rencana yang ditetapkan. Berdasarkan evaluasi kebijakan akan diketahui keberhasilan atau kegagalan sebuah kebijakan sehingga dapat disusun rekomendasi apakah kebijakan yang dibuat dapat dilanjutkan; atau perlu perbaikan sebelum dilanjutkan, atau bahkan harus dihentikan.

Menurut James P. Lester dan Joseph Stewart, Jr, evaluasi kebijakan dapat dibedakan ke dalam dua tugas yang berbeda. Tugas pertama adalah menentukan konsekuensi yang ditimbulkan oleh suatu kebijakan dengan cara menggambarkan dampaknya, sedangkan tugas kedua adalah untuk menilai keberhasilan atau kegagalan dari suatu kebijakan berdasarkan standar atau kriteria yang telah ditetapkan sebelumnya (dalam Winarno, 2012).

Adapun untuk menilai keber-hasilan suatu kebijakan perlu dikembangkan beberapa indikator. Indikator atau kriteria evaluasi yang dikembangkan oleh William N. Dunn (Dunn, 1999), yaitu:

a. Efektifitas: apakah hasil yang diinginkan telah tercapai? Berkaitan dengan apakah suatu kebijakan telah mencapai hasil (akibat) yang diharapkan, atau mencapai tujuan dari diadakan-nya tindakan. 
b. Kecukupan: seberapa jauh hasil yang telah tercapai dapat memecahkan masalah? Berkaitan dengan jumlah usaha yang diperlukan atau yang telah dilakukan untuk untuk mencapai tujuan.

c. Pemerataan: apakah biaya dan manfaat didistribusikan merata kepada kelompok masyarakat yang berbeda? Keadilan yang diberikan dan diperoleh sasaran kebijakan publik, keadaan di mana kebijakan publik dirasakan dan memberikan dampak yang berbeda pada masyarakat atau kelompok masyarakat tertentu.

d. Responsivitas: apakah hasil kebijakan memuat preferensi/nilai kelompok dan dapat memuaskan? Seberapa jauh suatu kebijakan dapat memuaskan kebutuhan, preferensi, atau nilai kelompok-kelompok masyarakat tertentu, suatu keberhasilan kebijakan dapat dilihat dari tanggapan masyarakat terhadap pelaksanaan kebijakan.

e. Ketepatan: apakah hasil yang dicapai bermanfaat? Menyangkut kepada produk yang telah dihasilkan dan dampak yang ditimbulkan pada sasaran kegi-atan.

\section{Pemberdayaan Masyarakat}

Menurut Ife dan Tesoriero, "pemberdayaan berarti menyediakan sumber daya, kesempatan, pengetahuan dan keterampilan untuk meningkatkan kemampuan masyarakat dalam menentukan masa depan mereka sendiri dan berpartisipasi serta mempengaruhi kehidupan ma-syarakatnya”. Dari definisi ini terlihat bahwa pemberdayaan bukan sekedar menolong orang miskin agar menjadi tidak miskin, namun lebih diarahkan kepada peningkatan ke-mampuan masyarakat untuk mandiri, dapat mengendalikan masa depannya dan bahkan dapat mempengaruhi orang lain (www.oceannaz. wordpress.com).

Jika dilihat dari proses operasionalisasinya maka ide pemberdayaan memiliki dua kecenderungan, antara lain: Pertama, kecenderungan primer, yaitu kecenderungan proses yang memberikan atau mengalihkan sebagian kekuasaan, kekuatan, atau kemampuan (power) kepada masyarakat atau individu menjadi lebih berdaya. Kedua, kecenderungan sekunder, yaitu kecenderungan yang menekankan pada proses stimulasi, mendorong atau memotivasi individu agar berkemampuan atau berdaya untuk menentukan yang menjadi pilihan hidupnya melalui proses dialog. Dua kecenderungan tersebut memberikan penekanan pada titik ekstrem seolah berseberangan, namun seringkali untuk mewujudkan kecenderungan primer harus melalui kecenderungan sekunder terlebih dahulu (Hadi, 2008). 
Dalam upaya memberdayakan masyarakat dapat dilihat dari tiga sisi, yaitu (Hadi, 2008):

1) Pertama, menciptakan suasana yang memungkinkan potensi masyarakat untuk berkembang (enabling). Setiap manusia, memiliki potensi yang dapat dikembangkan, artinya tidak ada masyarakat yang tanpa daya. Pemberdayaan adalah upaya untuk membangun daya itu, dengan mendorong, memotivasi, dan membangkitkan potensi yang dimilikinya serta berupaya untuk mengembangkannya.

2) Kedua, memperkuat potensi atau daya yang dimiliki masyarakat (empowering). Dalam rangka ini diperlukan langkah-langkah yang lebih positif, selain dari hanya menciptakan iklim dan suasana juga menyangkut penyediaan berbagai masukan, serta pembukaan akses ke berbagai peluang yang membuat masyarakat menjadi berdaya. Pemberdayaan bukan hanya meliputi penguatan individu anggota masyarakat, tetapi juga pranata-pranatanya.

3) Ketiga, memberdayakan mengandung arti melindungi. Dalam proses pemberdayaan harus dicegah yang lemah bertambah lemah karena ketidakberdayaan menghadapi yang kuat. Oleh karena itu, perlindungan dan pemihakan kepada yang lemah amat mendasar sifatnya dalam konsep pemberdayaan masyarakat. Melindungi tidak berarti mengisolasi atau menutupi dari interaksi, namun dilihat sebagai upaya untuk mencegah terja-dinya persaingan yang tidak seimbang, serta eksploitasi yang kuat atas yang lemah.

Memberdayakan masyarakat adalah upaya untuk meningkatkan harkat dan martabat masyarakat yang dalam kondisi tidak mampu untuk melepaskan diri dari perangkap kemiskinan dan keterbelakangan. Dengan kata lain, memberdayakan adalah memampukan dan meman-dirikan masyarakat meskipun pemberdayaan masyarakat bukan semata-mata sebuah konsep ekonomi. Dari sudut pandang kita, pemberdayaan masyarakat secara implisit mengan-dung arti menegakkan demokrasi ekonomi (Kartasasmita, 2003).

Desa

Desa menurut UU Nomor 6/2014 tentang Desa adalah desa dan desa adat sebagai kesatuan masya-rakat hukum yang memiliki batas wilayah yang berwenang untuk mengatur dan mengurus urusan pemerintahan, kepentingan masyarakat setempat 
berdasarkan prakarsa masyarakat, hak asal usul, dan/atau hak tradisional yang diakui dan dihormati dalam sistem pemerintahan Negara Kesatuan Republik Indonesia.

Pemerintahan Desa menurut UU no. 6/2014 tentang Desa adalah penyelenggaraan urusan pemerin-tahan dan kepentingan masyarakat setempat dalam sistem pemerintahan Negara Kesatuan Republik Indonesia.

\section{Badan Usaha Milik Desa (BUMDes)}

BUMDes menurut UU Nomor 6/2014 tentang Desa maupun Permendesa PDTT nomer 4 Tahun 2015 tentang Pendirian, Pengurusan Dan Pengelolaan, dan Pembubaran Badan Usaha Milik Desa adalah badan usaha yang seluruh atau sebagian besar modalnya dimiliki oleh desa melalui penyertaan secara langsung yang berasal dari kekayaan desa yang dipisahkan guna mengelola aset, jasa pelayanan, dan usaha lainnya untuk sebesarbesarnya kesejahteraan masyarakat desa.

Pembentukan BUMDes telah tersurat dalam Undang-Undang Re-publik Indonesia Nomor 32 Tahun 2004 tentang Pemerintahan Daerah di mana disebutkan desa dapat mendirikan badan usaha milik desa sesuai dengan kebutuhan dan potensi desa (Pasal 213: Ayat 1). Sejak diterbitkannya Peraturan Pemerintah Republik Indonesia Nomor 72 Tahun 2005 tentang Desa yang kemudian diperbaharui dengan Undang-Undang Republik Indonesia Nomor 6 Tahun 2014 tentang Desa, menjadi penegas dorongan tentang pendirian BUMDes.

Namun baru pada tahun 2010 mekanisme pembentukan dan operasionalisasi BUMDes diseragamkan dan dijelaskan oleh Pemerintah Pusat melalui terbitnya Peraturan Menteri Dalam Negeri (Permendagri) Nomor 39 Tahun 2010 tentang Badan Usaha Milik Desa. Kemudian diperbaharui pada tahun 2015 dengan Permendesa PDTT Nomor 4 Tahun 2015 tentang Pendirian, Pengurusan Dan Pengelolaan, dan Pembubaran Badan Usaha Milik Desa.

\section{Metode Penelitian}

Dalam penelitian ini digunakan penelitian kualitatif dengan pendekatan deskriptif. Menurut Bogdan dan Taylor (dalam Moleong, 1997:3) penelitian kualitatif adalah prosedur penelitian yang menghasilkan data deskriptif berupa kata-kata tertulis atau lisan dari orang-orang dan perilaku yang diamati. Hasil penelitian dirancang untuk mengumpulkan informasi tentang keadaan nyata dengan memberikan gambaran atau 
deskripsi secara sistematis, faktual dan akurat terhadap objek yang akan diteliti. Deskriptif merupakan laporan yang berisi kutipan data untuk memberikan gambaran penyajian laporan. Data tersebut berasal dari naskah, wawancara, dan dokumen resmi lainnya.

Fokus dalam penelitian ini adalah (1) efektifitas pendirian BUMDes Rejo Mulyo, (2) seberapa besar manfaat yang diberikan, (3) faktor yang menjadi pendukung dan penghambat dalam peningkatan perekonomian Desa Gogik.

Penelitian ini dilaksanakan pada BUMDes Rejo Mulyo, Desa Gogik, Kecamatan Ungaran Barat, Kabupaten Semarang. Dalam penelitian ini menggunakan data primer dan data sekunder, data primer diperoleh dari data-data yang dikumpulkan dari sumber data di lokasi penelitian, sedangkan data sekunder diolah dari dokumentasi yang dilakukan dari hasil wawancara, studi dokumentasi dan peng-amatan lapangan.

Dalam penelitian ini metode analisis yang digunakan adalah analisis data kualitatif, yaitu metode analisis yang digunakan untuk menganalisis data yang tidak dapat diterjemahkan dalam bentuk angka sehingga tidak dapat disusun ke dalam suatu struktur klasifikasi. Analisis dilakukan dengan menguraikan informasi-informasi yang diperoleh secara logis.

\section{PEMBAHASAN}

\section{Evaluasi Penyelanggaraan BUMDes Rejo Mulyo}

Secara normatif pendirian BUMDes Rejo Mulyo di Desa Gogik sudah melalui mekanisme yang benar sesuai dengan peraturan yang mengatur pendirian BUMDes. Ada beberapa potensi usaha masyarakat seperti LKD yang telah berjalan, ada sumber daya desa yang belum dimanfaatkan secara optimal semisal sumber mata air yang ada di Desa Gogik dan obyek wisata air terjun Semirang yang berada di wilayah desa. Dalam pendiriannya pun sudah melalui mekanisme Musdes, memiliki AD/ART hingga diterbitkannya Perdes yang mengatur BUMDes Rejo Mulyo.

Namun jika dilihat dengan seksama, pendirian BUMDes Rejo Mulyo bukan murni karena inisiatif pemerintah desa dan atau masyarakat, tetapi lebih karena dorongan dari Pemerintah dalam hal ini pemerintah pusat melalui program Desa Lab Site, di mana Desa Gogik menjadi salah satu lokasi kegiatannya. Hal ini menggambarkan sebenarnya pembentukan BUMDes secara riil bukan karena kebutuhan dan inisiatif masyarakat Desa 
Gogik maupun Pemerintah Desa Gogik sendiri untuk mengembangkan potensi dan meningkatkan pere-konomian desanya.

Keterlibatan masyarakat dalam musyawarah desa untuk pembentukan BUMDes Rejo Mulyo hal itu lebih bersifat sosialisasi program pemerintah tentang pendirian BUMDes, bukan sebuah proses diskusi masyarakat untuk mengatasi permasalahan dan meningkatkan perekonomian masyarakat. Namun secara teori, tiga unit usaha BUMDes Rejo Mulyo saat ini sesuai dengan potensi yang ada di Desa Gogik, yaitu keuangan mikro dalam hal ini dengan adanya Lembaga Keuangan Desa (LKD) Samirana, kemudian sumber air bersih yang melimpah dan obyek wisata. Dari potensi itu kemudian dibentuk Pengelolaan Air Bersih (PAB) dan Kelompok Sadar Wisata (Pokdarwis).

Pemahaman masyarakat ten-tang BUMDes Rejo Mulyo dapat dikatakan masih minim. Dari empat masyarakat yang dimintai keterangan, tiga diantaranya mengetahui keberadaan BUMDes Rejo Mulyo, namun tidak paham BUMDes itu organisasi/lembaga yang seperti apa dan bagaimana kegiatannya. Mereka memahami adanya BUMDes, LKD dan PAB itu sebagai sebuah organisasi/lembaga yang berdiri sendiri-sendiri, padahal LKD dan PAB merupakan bagian atau unit usaha dari BUMDes Rejo Mulyo.

Berkaitan dengan manfaat yang dirasakan masyarakat Desa Gogik dalam penyelenggaraan unit usaha BUMDes RejoMulyo, dapat disimpulkan bahwa pemerataan yang diberikan masih kurang baik. Wilayah kerja unit usaha dari BUMDes Rejo Mulyo masih belum merata di dua dusun wilayah Desa Gogik, yaitu Dusun Gogik dan Dusun Gintungan. Selain itu kegiatannya juga belum menyentuh seluruh elemen masyarakat desa, baru unit usaha LKD yang wilayah kerjanya sudah mencakup seluruh wilayah desa. Pemanfaatnya digunakan oleh beragam elemen masyarakat, jasa tabungan mayoritas justru anak-anak, sementara untuk kredit mulai dari yang berlatar belakang petani maupun wirausaha.

Sementara itu, unit usaha lain seperti PAB berdasarkan wilayah kerja baru dapat beroperasi di Dusun Gintungan saja karena permasalahan yang terjadi pada awal berdirinya. Namun dalam hal pemanfaat PAB baru dapat menyentuh seluruh elemen masyarakat yang berada di wilayah Dusun Gintungan saja. Untuk unit usaha Pokdarwis/Desa Wisata, sejak berdiri hingga saat ini belum melakukan kegiatan karena ada penghambat, yakni obyek wisata air terjun Semirang terletak di wilayah Perhutani dan sejak bulan Maret diserahkan pengelolaannya ke desa melalui LMDH. 
Disatu sisi BUMDes Rejo Mulyo mampu memberi manfaat positif mengatasi permasalahan ekonomi masyarakat Desa Gogik. Melalui unit usaha LKD dengan kredit usaha mikro mengatasi kebutuhan masyarakat dalam hal modal usaha. Dengan syarat mudah dan bunga ringan sangat membantu masyarakat desa yang membutuhkan dana segar dalam waktu yang cepat sehingga menghindarkan masyarakat dari cengkeraman rentenir.

Namun pada sisi yang lain BUMDes Rejo Mulyo masih belum dapat memberikan pendapatan yang sesuai kepada pegawainya. Hal itu terlihat dari pendapatan yang didapatkan dari BUMDes Rejo Mulyo masih di bawah UMR Kab. Semarang sehingga BUMDes belum dapat dijadikan mata pencaharian pokok para pengurus dan pegawai BUMDes Rejo Mulyo. Pada umumnya mereka memiliki usaha sampingan atau pekerjaan lain di luar BUMDes, namun demikian seolah-olah hal itu tidak memberikan pengaruh kepada para pengurus dan pegawainya, mereka tetap memberikan pelayanan yang baik kepada masyarakat Desa Gogik.

\section{Faktor yang menjadi pendukung dan penghambat dalam peningkatan pereko- nomian Desa Gogik}

\section{Faktor pendukung}

Faktor pendukung dalam penyelenggaraan BUMDes Rejo Mulyo adalah besarnya rasa cinta para Direksi dan pegawai BUMDes Rejo Mulyo kepada Desa Gogik. Tempat mereka tinggal menjadi faktor yang sangat menguatkan BUMDes sehingga mereka dengan senang hati mau melibatkan diri untuk ikut membangun perekonomian desa melalui BUMDes, walaupun pendapatan yang mereka dapatkan dari BUMDes Rejo Mulyo jauh dari cukup.

Faktor pendukung kedua adalah faktor kekayaan alam di Desa Gogik di mana memiliki kekayaan alam berupa air bersih yang cukup baik. Dari keterangan narasumber, ada beberapa sumber mata air yang bisa dimanfaatkan, yang terbesar adalah sumber mata air Semirang yang juga terdapat obyek wisata air terjun Semirang. Namun sayangnya kekayaan air itu belum dimanfaatkan secara optimal karena berada dalam wilayah hutan yang menjadi ranah wilayah Perhutani.

Berdasarkan hasil penelitian ini dapat disimpulkan bahwa keterbukaan Direktur dan Komisaris terhadap masukan dari masyarakat maupun para pegawai menjadi salah satu 
faktor pendukung ketiga dalam penyelenggaraan BUMDes Rejo Mulyo. Hal ini menjadi modal tersendiri untuk kemajuan penyelenggaraan BUMDes Rejo Mulyo ke depan.

\section{Faktor Penghambat}

Sementara itu ada beragam faktor yang menjadi penghambat dalam penyelenggaraan BUMDes Rejo Mulyo. Pertama potensi terbesar Desa Gogik, yaitu obyek wisata air terjun Semirang belum dikelola oleh BUMDes Rejo Mulyo. Hal ini mulai sedikit menemui titik terang dengan diserahkannya pengelolaan obyek wisata air terjun Semirang kepada LMDH. Sesegera mungkin beberapa pihak berharap obyek itu dapat dikelola BUMDes Rejo Mulyo dan pengelolaan ini diserahkan selamanya kepada desa.

Faktor penghambat yang kedua adalah masih adanya anggapan dari sebagian masyarakat yang memiliki rasa tanggung jawab rendah bahwa dana pinjaman dari LKD merupakan hibah dari pemerintah, tidak ada tanggung jawab mengembalikan. Dalam pandangan pihak yang berkompeten harus ada hukuman bagi mereka yang menunggak pelunasan kredit dari LKD.

Faktor penghambat yang ketiga adalah masalah personil, yaitu adanya tumpang tindih jabatan dalam BUMDes, sedangkan kekosongan personil dalam struktur direksi tidak segera diatasi. Hal ini menimbulkan beban bagi pegawai LKD yang membantu fungsi bendahara BUMDes dan tentunya menghambat kinerja mereka.

Faktor penghambat keempat adalah faktor komunikasi, mulai dari komunikasi internal antar Direksi, Komisaris dengan Direksi, maupun dengan Dewan Pengawas. Hal ini terlihat dari keterangan dari Dewan Pengawas yang selalu kontradiktif dengan keterangan Direksi dan Komisaris sehingga perlu untuk dibangun ulang komunikasi antar unsur internal di dalam BUMDes Rejo Mulyo.

Faktor penghambat kelima adalah keaktifan pengurus, dari observasi kami di lapangan dari tiga orang direksi hanya direktur yang aktif dalam penyelenggaraan BUMDes Rejo Mulyo. Selain posisi bendahara yang kosong, fungsi sekretaris juga tidak aktif, terlihat dari tidak teraturnya administrasi dari BUMDes Rejo Mulyo. Sebagai sebuah organisasi administrasi itu menjadi hal yang penting dalam mengukur tingkat keberhasilan dari organisasi tersebut. 


\section{PENUTUP}

\section{Kesimpulan}

Penelitian ini dapat disimpulkan beberapa poin sebagai berikut:

a. Secara normatif pendirian BUMDes Rejo Mulyo di Desa Gogik sudah melalui mekanisme yang benar, sesuai dengan peraturan yang mengatur pendirian BUMDes. Ada potensi desa yang belum di manfaatkan secara maksimal meskipun sudah melalui mekanisme Musdes. Adanya AD/ART hingga diterbitkannya Perdes yang mengatur BUMDes Rejo Mulyo, walaupun itu memang dorongan Pemerintah Pusat melalui Program Desa Lab Site sehingga lebih dominan.

b. Secara umum penyelenggaraan BUMDes Rejo Mulyo di Desa Gogik belum maksimal sesuai dengan yang dicita-citakan dalam dalam Permendagri no. 39/2010 tentang Badan Usaha Milik Desa dan Permendesa PDTT No. 4/2015 tentang Pendirian, Pengurusan Dan Pengelolaan, dan Pembubaran Badan Usaha Milik Desa. Benar memang BUMDes Rejo Mulyo telah mampu memberikan kontribusi ke PADes Desa Gogik \pm Rp. 5.000.000 setiap tahunnya, namun kontribusinya dalam mendukung kesejahteraan masyarakat Desa Gogik masih kurang sehingga perlu untuk dilakukan pembenahan supaya penyelenggaraan BUMDes Rejo Mulyo mampu memberikan dampak yang lebih maksimal.

c. Berkaitan dengan ketaatan terhadap AD/ART BUMDes itu sendiri perlu ditingkatkan, dengan ditetapkannya AD/ART seharusnya itu menjadi patokan dalam penyelenggaraan BUMDes Rejo Mulyo. Namun pada kenyataannya banyak yang berjalan tidak sesuai dengan AD/ART contohnya seperti dalam pelaksanaan PAB. Bagaimanapun juga sesuai AD/ART PAB itu merupakan unit usaha dari BUMDes Rejo Mulyo, namun kenyataannya tidak demikian karena kesepakatan bersama supaya PAB dapat berjalan lancar dulu tidak dibebani tanggung jawab apapun kepada organisasi induknya.

d. Adapun yang menjadi faktor pendukung dalam penyeleng-garaan BUMDes Rejo Mulyo adalah semangat dan kerelaan para pengurus dan pegawai untuk mengabdi kepada Desa Gogik. Ini menjadi kunci pokok dalam penyelenggaraan BUMDes Rejo Mulyo ini, karena para pengurus dan pegawai dengan rela hati mendapatkan gaji yang jauh dari UMR, namun semangat mereka masih tinggi dalam mengem-bangkan BUMDes ini. 
e. Faktor pendukung kedua adalah faktor kekayaan alam di Desa Gogik. Tidak bisa dipungkiri Desa Gogik memiliki kekayaan alam berupa air bersih yang cukup baik, ada beberapa sumber mata air yang dimanfaatkan masyarakat sebagai sumber air bersih. Yang terbesar adalah sumber mata air Semirang yang juga terdapat obyek wisata air terjun Semirang. Kekayaan alam ini jika dikelola dan dimanfaatkan dengan maksimal dapat memberikan manfaat yang lebih ke BUMDes dan PADes.

f. Faktor pendukung ketiga adalah keterbukaan Direktur dan Komisaris terhadap masukan dari masyarakat maupun para pegawai sehingga menjadi modal tersendiri untuk kemajuan penyelenggaraan BUMDes Rejo Mulyo ke depan.

g. Sementara itu ada beragam faktor penghambat dalam penyelenggaraan BUMDes Rejo Mulyo, yang pertama adalah hubungan komunikasi yang kurang baik/terbuka antara Komisaris, Direksi dengan Dewan Pengawas dapat menjadi batu sandungan tersendiri dalam kelangsungan BUMDes Rejo Mulyo.

h. Faktor penghambat kedua adalah kredit macet yang terjadi di LKD Samirana dengan jumlah yang tidak sedikit. Selama ini penindakan kredit macet tersebut diselesaikan dengan cara kekeluargaan, namun sepertinya masyarakat yang mempunyai kredit macet tersebut mempunyai sifat membandel.

i. Faktor penghambat ketiga adalah masalah personil, adanya tumpang tindih jabatan dalam BUMDes, kekosongan personil dalam struktur direksi, tidak segera diatasi. Hal ini menimbulkan beban bagi pegawai LKD yang membantu fungsi bendahara BUMDes dan tentunya menghambat kinerja mereka.

j. Faktor penghambat keempat adalah tentang keaktifan pengurus. Dari observasi kami di lapangan terhadap tiga orang direksi, hanya direktur yang aktif dalam penyelenggaraan BUMDes Rejo Mulyo, fungsi sekretaris tidak aktif, terlihat dari tidak teraturnya administrasi dari BUMDes Rejo Mulyo.

k. Faktor penghambat kelima adalah potensi alam terbesar yang ada di Desa Gogik, yaitu air terjun Semirang belum dapat dimanfaatkan karena berada di wilayah Perhutani. Baru pada awal tahun 2016 pengelolaan diserahkan LMDH. 


\section{DAFTAR PUSTAKA}

Buku Panduan Pendirian dan Pengelolaan Badan Usaha Milik Desa (BUMDes), 2007, Departemen Pendidikan Nasional Pusat Kajian Dinamika Sistem Pembangunan (PNPKDSP) Fakultas Ekonomi Universitas Brawijaya, Malang.

Dunn, W, 1999, Pengantar Analisis Kebijakan Publik. Gadjah Mada University Press, Yogyakarta.

Lexy J, Dr Moleong, 1997, Metode Penelitian Kualitatif, P.T. Remaja Rosdakarya, Jakarta.

Subarsono, A.G, 2008, Analisis Kebijakan Publik, Pustaka Pelajar, Yogyakarta.

Wahab, Solichin Abdul, 1989, Pengantar Analisis Kebijakan Negara, Bhineka Cipta, Jakarta.

Winarno, Budi, 2012, Kebijakan Publik: Teori dan Proses, Media Pressindo, Yogyakarta. Undang-Undang Republik Indonesia Nomor 32 Tahun 2004 tentang Pemerintahan Daerah.

Undang-Undang Republik Indonesia Nomor 6 Tahun 2014 tentang Desa.

Peraturan Menteri Dalam Negeri Nomor 39 Tahun 2010 tentang Badan Usaha Milik Desa.

Peraturan Menteri Menteri Desa, Pembangunan Daerah Tertinggal, dan Transmigrasi (Permendesa PDTT) nomor 4 Tahun 2015 tentang Pendirian, Pengurusan Dan Pengelolaan, dan Pembubaran Badan Usaha Milik Desa.

Anggaran Dasar/Anggaran Rumah Tangga (AD/ART) Badan Usaha Milik Desa (BUMDes) Rejo Mulyo 2012-2015, Desa Gogik, 30 Desember 2011.

Kartasasmita, Ginandjar, "PEMBERDAYAAN MASYARAKAT": Konsep Pembangunan Yang Berakar Pada Masyarakat" (Bahan Kuliah SP 605 Program Pasca Sarjana ITB Jakarta, 1 Desember 2003)

Konsep Pemberdayaan, Partisipasi dan Kelembagaan Dalam Pembangunan oleh Agus Purbathin Hadi (Pusat Pengembangan Masyarakat Agrikarya (PPMA)), 2008.

Laporan Kegiatan Badan Usaha Milik Desa (BUMDes) Rejo Mulyo, Desa Gogik, Kecamatan Ungaran Barat, Kabupaten Semarang Tahun 2012

Administrator. (2010, 29 Juli). PEMBERDAYAAN MASYARAKAT. Diperoleh 25 Juli 2014, dari http://oceannaz.wordpress.com/2010/07/29/pemberdayaan-masyarakat/ 